\title{
Pengaruh proporsi biji nangka (Artocarpus heterophyllus L.) dan kacang hijau (Phaseolus radiatus $\mathbf{L}$.) pada pembuatan sosis nabati
}

\author{
Effect of proportion of jackfruit seeds (Artocarpus Heterophyllus L.) and green beans \\ (Phaseolus radiatus L.) in making vegetable sausage
}

\author{
Kunti Mufarikha ${ }^{1)}$, Muh Aniar Hari Swasono ${ }^{1 *}$, Deny Utomo ${ }^{1)}$ \\ ${ }^{1}$ Program Studi Ilmu dan Teknologi Pangan, Universitas Yudharta Pasuruan, \\ Pasuruan, Jawa Timur \\ *Email korespondensi: aniarhari@yudharta.ac.id \\ Informasi Artikel: \\ Dikirim: 21/08/2020; disetujui: 15/12/2020; diterbitkan: 30/03/2021
}

\begin{abstract}
Jackfruit seeds and green beans can be used as a substitute for animal protein in making sausages. The purpose of this study was to obtain the right proportion of jackfruit seeds to the correct addition of mung bean flour for the manufacture of vegetable sausage products in terms of physicochemistry and organoleptic. The method used in this study was a 2 factor completely randomized design consisting of 9 treatments and three replications. The treatments were given in the form of the proportion of jackfruit seed flour (N1: 25\%, N2: 50\%, N3: 75\%) with green beans (K1: 25\%, K2: 50\%, K3: 75\%). The parameters measured were protein content test(Method Kjeldahl), texture (Method Texture Profile Analysis), and sensory test (Hedonic Method, Soekarto 1985). The sensory test used is a hedonic scale with 25 untrained panelists. Test of protein content and texture used data from the previous research literature. The results of this study indicated that the higher the proportion of jackfruit seeds and green beans had a significant effect on the parameters of protein content, texture, and organoleptic properties. From literary data, the best parameter of protein content is N3K1 (75\% jackfruit seed flour $+75 \%$ green bean flour). While the best organoleptic value is the proportion of N1K3 (25\% jackfruit seed flour $+25 \%$ green bean flour).
\end{abstract}

Keywords: Jackfruit seeds, green beans, sausages

\begin{abstract}
ABSTRAK
Biji nangka dan kacang hijau dapat digunakan sebagai pengganti protein hewani dalam pembuatan sosis. Tujuan dari penelitian ini adalah mendapatkan proporsi yang tepat untuk biji nangka terhadap produk penambahan tepung kacang hijau yang tepat untuk pembuatan produk sosis nabati ditinjau dari fisikokimia dan organoleptik. Metode yang digunakan dalam penelitian ini adalah Rancangan Acak Lengkap 2 faktor terdiri dari 9 perlakuan. Perlakuan yang diberikan berupa proporsi tepung biji nangka $\left(\mathrm{N}_{1}: 25 \%\right.$, $\left.\mathrm{N}_{2}: 50 \%, \mathrm{~N}_{3}: 75 \%\right)$ dan kacang hijau $\left(\mathrm{K}_{1}: 25 \%, \mathrm{~K}_{2}: 50 \%, \mathrm{~K}_{3}: 75 \%\right)$. Parameter yang diukur adalah Uji kadar protein (Metode Kjedahl), Kekenyalan (Metode Texture Profile Analysis) dan Uji Sensoris (Metode Hedonik, Soekarto 1985). Uji sensorik menggunakan skala hedonik dengan 25 panelis tidak terlatih. Uji kadar protein dan Tekstur menggunakan data literatur penelitian terdahulu. Hasil penelitian ini menunjukkan semakin tinggi proporsi biji nangka dan kacang hijau berpengaruh nyata terhadap parameter kadar protein, tekstur dan sifat organoleptik. Dari data literatur parameter kadar protein terbaik adalah N3K1(tepung biji nangka 75\%+tepung kacang
\end{abstract}


hijau $75 \%$ ). Sedangkan nilai organoleptik terbaik yaitu proporsi N1K3 (tepung biji nangka 25\%+tepung kacang hijau 25\%)

Kata kunci : Biji nangka, Kacang hijau, Sosis

\section{PENDAHULUAN}

Di Indonesia produksi nangka berkisar 720.208 ton per tahun, (BPS, 2012).Buah nangka memiliki biji berwarna cokelat muda (endocarp) yang berukuran panjang $2-4 \mathrm{~cm}$. Pada satu buah nangka terdapat 100-200 atau hingga 500 biji nangka (Thelvasanthi et al, 2011). Biji nangka (Artocarpusheterophyllus L.) mengandung nilai gizi yang tinggi berupa protein, fosfor, kalsium, zat besi serta mengandung antioksidan prenylflavones (Gupta et al, 2016). Biji nangka merupakan sumber makanan lokal yang potensial, namun selama ini biji nangka kurang dimanfaatkan oleh masyarakat, biji nangka biasanya dimanfaatkan sebagai pakan ternak atau limbah. Untuk meningkatkan nilai ekonomisnya biji nangka dapat diolah menjadi tepung (Jayus, Setiawan dan Giyarto, 2016). Tepung biji nangka yang dihasilkan dimaksudkan untuk memperpanjang umur simpan produk, meningkatkan nilai gizi serta memudahkan penggunaan aplikasi produk jika dibandingkan dengan biji nangka yang belum melalui proses penepungan (Rizal et al., 2013). Tepung biji nangka mengandung komponen gizi yaitu protein sebesar 5,78 gram, karbohidrat 71,76 gram, dan lemak 1,77 gram pada 100 gram tepung biji nangka (Islam et al., 2015). Biji nangka juga mengandung mineral seperti kalsium, fosfor, dan zat besi, selain itu juga mengandung vit a, vit, $\mathrm{c}$ dan vit B1. (Nusa, Fuadi dan Fatimah, 2014). Kacang hijau (Phaseolus radiatus L.) memiliki kandungan gizi yang tinggi protein sebesar 22\%, karbohidrat $64 \%$, lemak $0,96 \%$, kadar abu $3,75 \%$, kadar air 7,6\% (Adiandri, Hidayah dan Rahayu, 2014). Selain mengandung mineral yang tinggi, kacang hijau juga mengandung polifenol, karotenoid, asam askorbat, toferol dengan konsentrasi yang tinggi (Chaurasia et al., 2014). Kacang hijau dimasak berkuah atau kering, diolah menjadi tepung, sup, bubur, makanan ringan, atau sebagai tambahan pangan pada roti, mie dan ice cream (Bayode, 2020).

Sosis adalah produk olahan daging yang diproses dengan cara dihaluskan dan diawetkan, sehingga dapat diolah kembali menjadi berbagai hidangan dan memiliki daya simpan yang tinggi karena proses pengawetan melalui proses penggaraman (Apsittiwong et al., 2018). Sosis memiliki kandungan protein dan kadar lemak jenuh yang tinggi (Hidayat et al., 2017). Sosis biasanya mengandung lemak jenuh sebesar 30\% (Sisik et al., 2012), sehingga apabila dikonsumsi berlebihan dapat menyebabkan jantung koroner dan gangguan kesehatan yang lainnya (Kim et al., 2019).

Permasalahan yang sering muncul pada pembuatan sosis nabati yaitu memisahnya komponen-komponen adonan sosis karena kurangnya emulsi minyak atau lemak dalam air dan protein nabati, tingkat kekenyalan sosis seperti sosis yang terlalu keras atau terlalu lunak (Sisik et al., 2012).Berdasarkan permasalahan dalam pembuatan sosis nabati tersebut, pada penelitian ini akan diteliti pengaruh proporsi biji nangka dan kacang hijau pada pembuatan sosis nabati. Biji nangka selain berguna sebagai bahan pengisi atau bahan pengganti tepung terigu karena memiliki kandungan amilosa tinggi sebesar $26,57 \%$ - 31,37\% (Noor et al., 2014). Kandungan amilosa yang tinggi akan mempermudah mengikat air dan memberikan tekstur kenyal pada sosis. Selain itu akan ditambahkan tepung kacang hijau yang merupakan sumber protein dan sebagai emulsifier dalam mengikat lemak dan air pada sosis (Prayitno et al., 2012).

\section{METODE}

\section{Bahan}

Bahan baku utama yang digunakan untuk pembuatan sosis nabati adalah kacang hijau dibeli di Pasar Bangil dan tepung biji nangka yang dibeli secara online dengan 
produk yang telah berstandar BPOM. Bahan tambahan yang digunakan adalah tepung terigu, casing selulosa, bawang putih, merica, baking powder, garam dan air. Seluruh bahan baku diperoleh dari Pasar Bangil, pasuruan.

\section{Alat}

Alat yang digunakan dalam penelitian ini yaitu neraca analitik, ayakan mesh 60 mesh, pisau, kompor, oven, panci, kertas saring.

\section{Metode/ Pelaksanaan}

Rancangan penelitian yang digunakan adalah Rancangan Acak Lengkap (RAL) 2 faktor terdiri dari 9 perlakuan. Perlakuan yang diberikan berupa:

$\mathrm{N} 1 \mathrm{~K} 1=$ Tepung biji nangka $25 \%$ + tepung kacang hijau $75 \%$

$\mathrm{N} 1 \mathrm{~K} 2=$ Tepung biji nangka $25 \%$ + tepung kacang hijau $50 \%$

N1K3= Tepung biji nangka $25 \%$ + tepung kacang hijau $25 \%$

$\mathrm{N} 2 \mathrm{~K} 1=$ Tepung biji nangka $50 \%$ + tepung kacang hijau $75 \%$

$\mathrm{N} 2 \mathrm{~K} 2=$ Tepung biji nangka $50 \%$ + tepung kacang hijau $50 \%$

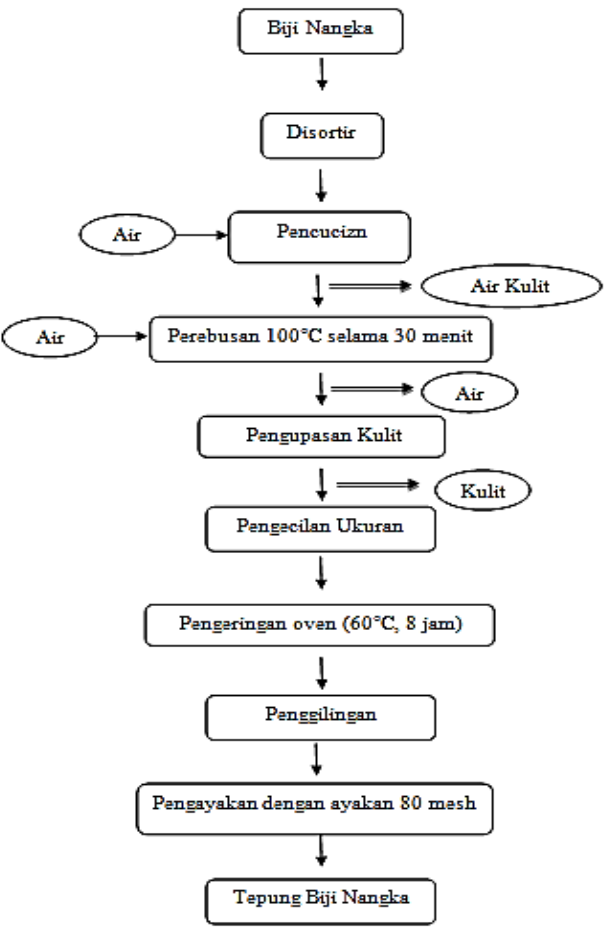

Gambar1. Proses pembuatan tepung nangka muda (nuriana, 2010)
$\mathrm{N} 2 \mathrm{~K} 3=$ Tepung biji nangka 50\% + tepung kacang hijau $25 \%$

$\mathrm{N} 3 \mathrm{~K} 1=$ Tepung biji nangka $75 \%$ + tepung kacang hijau $75 \%$

N3K2= Tepung biji nangka $75 \%$ + tepung kacang hijau 50\%

N3K3= Tepung biji nangka 75\% + tepung kacang hijau $25 \%$

Masing-masing dari perlakuan terdiri dari 3 ulangan sehingga diperoleh 27 kombinasi perlakuan. Parameter fisik kimia yang diukur yaitu kadar protein (Metode Kjedahl), kekenyalan (Metode Texture Profile Analysis) dan uji organoleptik sosis nabati. Pengujian kadar protein dan kekenyalan diperoleh dari mereview dari beberapa jurnal dan artikel ilmiah pada sosis nabati, Sedangkan sifat organoleptik diperoleh dari uji organoleptik kesukaan (hedonic) skor menggunakan 25 orang panelis meliputi rasa, aroma, warna dan tekstur. dengan 4 skala, yaitu 1= Sangat tidak suka, 2= Tidak suka, 3= Suka, 4= Sangat suka. Proses pembuatan sosis nabati berbahan tepung biji nangka dan tepung kacang hijau sebagai berikut:

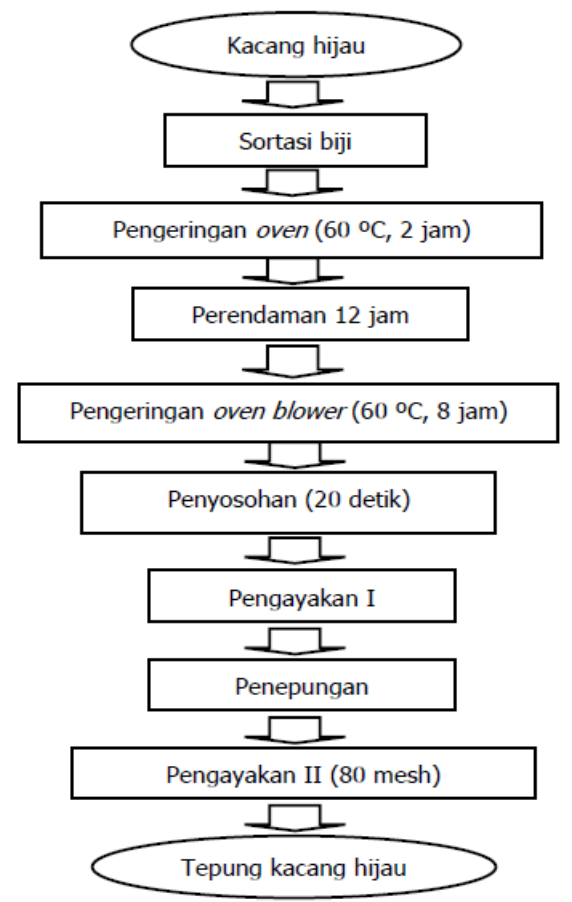

Gambar 2. Proses pembuatan tepung kacang hijau (Adiandri et al., 2014) 


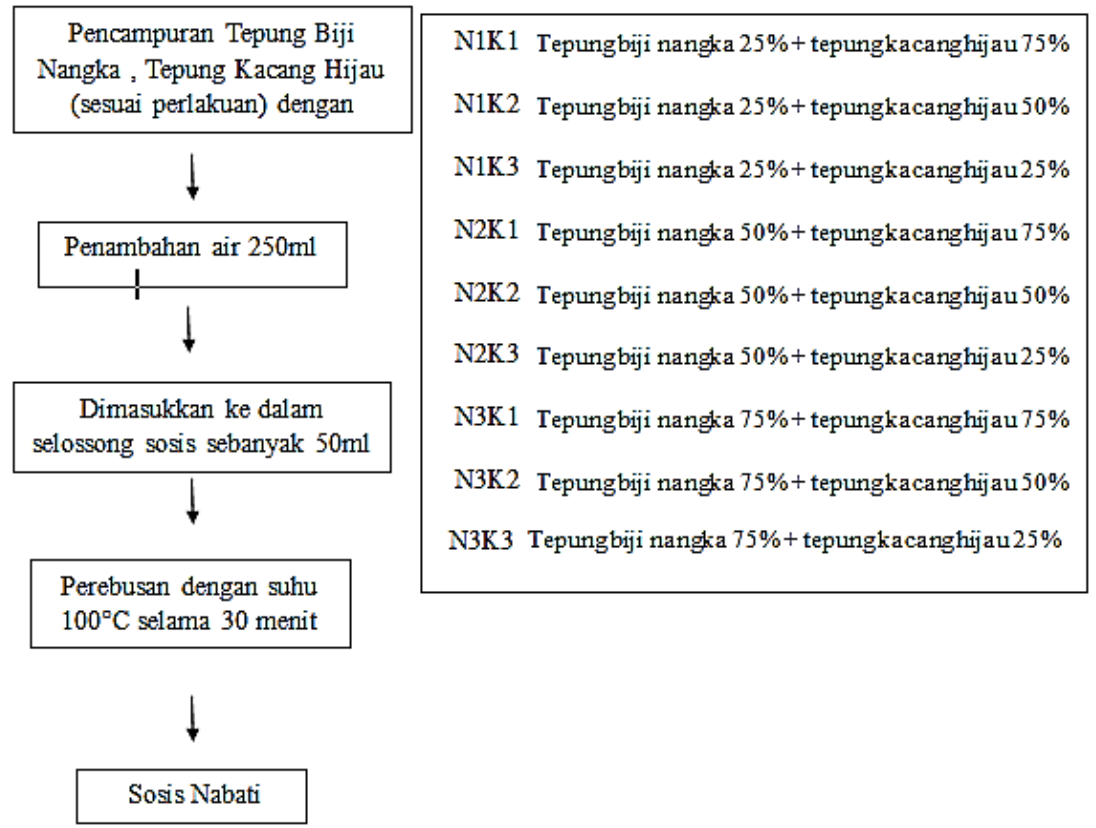

Gambar 3. Proses pembuatan sosis nabati (Sofiana, 2012)

\section{HASIL DANPEMBAHASAN}

\section{Kadar protein}

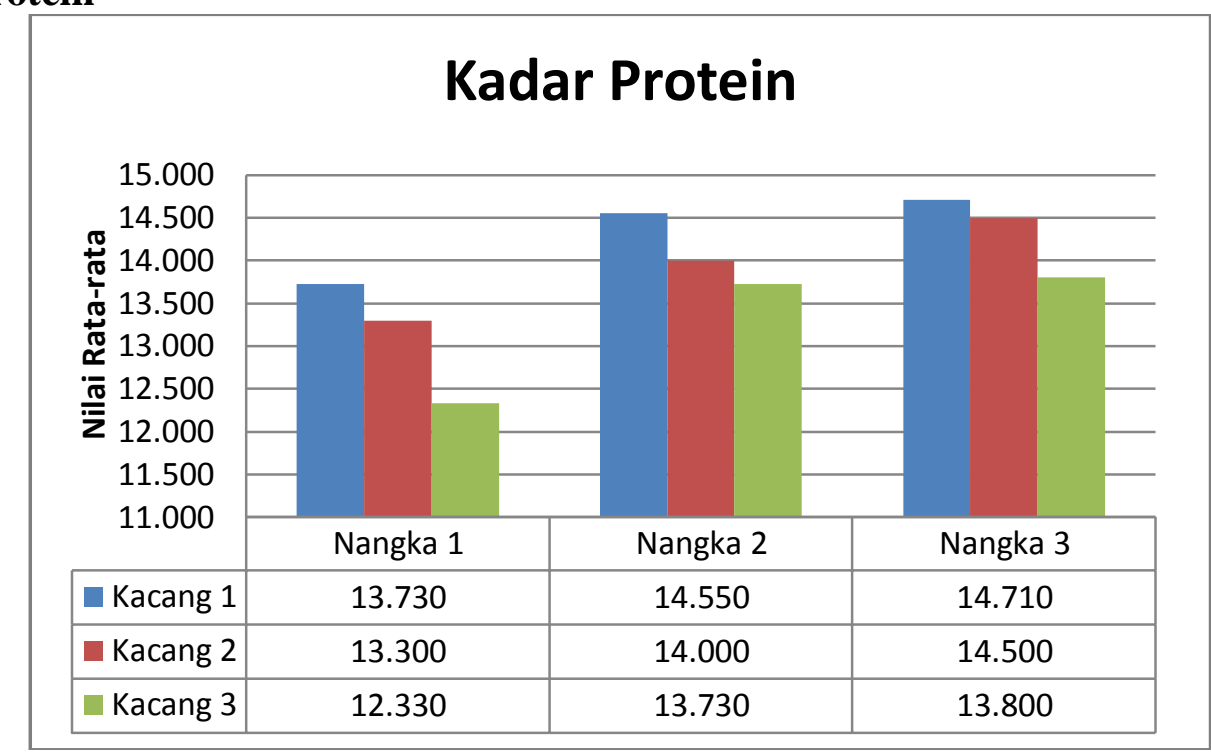

Gambar 4. Garfik rata - rata kadar protein sosis nabati (Singal et al., 2013; Ambari, 2014; Pradipta dan Putri, 2015; Andyarini et al., 2017; Hadi et al., 2017; Requinta et al., 2017)

Dari hasil studi literatur menyebutkan bahwa pada perlakuan sosis nabati terhadap penambahan tepung kacang hijau dan tepung biji nangka berpengaruh signifikan pada kandungan kadar protein. Pada penelitian Requinta et al., 2017 menunjukkan hasil yang beda nyata dengan tingkat kepercayaan 95\% pada kadar protein yang diperoleh berdasarkan hasil pengujian sosis tepung

tempe koro benguk dan labu kuning yaitu berkisar antara 23, 66\% - 26, $59 \%$ dengan semakin bertambahnya penambahan konsentrasi koro benguk, namun pengurangan konsentrasi labu kuning tidak mempengaruhi kandungan protein pada sosis. Hal ini dikarenakan kandungan protein koro benguk sekitar 32,3\% (Pratama et al., 2008; Requinta et al., 2017), dan pada labu 
kuning memiliki kandungan protein 5\% (Prayitno et al., 2012). Sosis analog dengan bahan baku tempe dan perlakuan penambahan jamur tiram 20\%, menunjukkan segnifikan $\mathrm{p}<0,05$ dengan kadar protein berkisar antara $14,40 \%$ - $14,60 \%$ sesuai dengan SNI 01-3820-1995 kadar protein pada sosis yaitu min 13\% (Ambari, Anwar, dan Damayanthi, 2014). Penambahan labu kuning sebagai bahan pengisi sosis menghasilkan kadar protein yang beda nyata $(\mathrm{P}<0,01)$, hasil penelitian berkisar $12,68 \%$ sampai 15,32\% (Prayitno et al., 2012). Pada perlakuan penambahan tepung porang dan tepung maizena pada sosis ayam menghasilkan rerata kadar protein berkisar antara 11,73\% sampai dengan 12,31 \% (Anggraeni, Widjanarko dan Ningtyas,2014). Peningkatan kandungan protein sosis ikan gabus berbanding lurus dengan peningkatan penambahan tepung wortel. Hal ini disebabkan karena di dalam tepung wortel juga mengandung protein sebesar $4,75 \%$ (Nuansa, 2011), Kandungan protein dalam ikan gabus segar $(25,2 \%)$ (Singal et al., 2013). Pada penambahan angkak tidak mempengaruhi kandungan protein pada sosis, karena kandungan protein pada angkak yang rendah sekitar 11,60\% (Atma, 2015). Sedangkan kandungan protein pada kacang hijau yaitu sebesar 22\% (Purwono, 2012) dan kandungan protein pada tepung biji nangka sebesar 12, 19\% (Andyarini et al., 2017). Sehingga penambahan konsentrasi di antara tepung kacang hijau dan tepung biji nangka sangat mempengaruhi kandungan protein pada sosis nabati.

Penambahan biji nangka mempengaruhi meningkatnya kandungan protein pada sosis nabati. Dari hasil studi literatur Sultana et al. (2014) menyebutkan bahwa penambahan konsentrasi tepung biji nangka 5\%, $15 \%$ dan $25 \%$ memiliki rerata kadar protein sebesar $11,63 \%$ - 12,95\%. Biji nangka memiliki kandungan protein sebesar $11.85 \%$ (Abedin, 2012). Tepung biji nangka pada konsentrasi $25 \%$, 50\%, dan $75 \%$ pada tortila menunjukkan beda nyata pada BNT $1 \%=0,52$ dan menunjukkan peningkatan kandungan protein
9,8\%-10,26\% (Dolongseda, Ludong, dan Djarkasi, 2017).

Kadar protein pada flakes semakin rendah dengan semakin rendahnya konsentrasi tepung biji nangka yang ditambahkan, penambahan tepung biji nangka pada konsentrasi $100 \%$, $90 \%, 80 \%$, $70 \%$ dan $60 \%$ menunjukkan kadar protein berturut-turut sebesar 11,76\%, 11,06\%, $10,36 \%, 9,80 \%$, dan 9,26\% (Hadi, Yusmarini dan Efendi, 2017). Kadar protein meningkat seiring dengan penambahan konsentrasi kacang hijau. Dari hasil studi literatur menyebutkan kadar protein pada biskuit kacang hijau yang disubtitusi dengan tepung bekatul cenderung meningkat akibat meningkatnya proporsi kacang hijau yang ditambahkan, rerata kadar protein 7\%-9\% hal ini dikarenakan kadar protein tepung bekatul lebih rendah dibanding kadar protein tepung kacang hijau, namun pada penelitian ini penambahan proporsi tepung bekatul lebih banyak jika dibandingkan proporsi tepung kacang hijau, sehingga kadar protein pada biskuit relatif rendah (Pradipta dan Putri, 2015).

Kadar protein dalam foodbar dengan penambahan tepung kacang hijau lebih rendah dari kedelai yaitu sebesar 23,25\% (Ekafitri, 2014). Pada penelitian Pratama et al.(2014) proporsi tepung terigu dan tepung kimpul pada mie kering dengan penambahan tepung kacang hijau berkisar antara 8.84 $14.01 \%$.semakin meningkat proporsi tepung kacang hijau maka kadar protein juga semakin meningkat. Rerata kadar protein pada foodbars dengan berbagai perlakuan berkisar antara 5,60\% - 9,44\% memberikan pengaruh yang signifikan $\mathrm{p}=0,05$, kadar protein cenderung meningkat dengan meningkatnya proporsi kacang hijau yang ditambahkan (Ladamay et al., 2014).

Dari hasil studi literatur menyebutkan penggantian bahan baku sosis dengan tepung kacang hijau dan tepung biji nangka memiliki kadar protein yang lebih rendah dibandingkan dengan sosis dengan bahan baku daging (Hidayat et al., 2017). Pada sosis ayam dengan penambahan proporsi gel porang menunjukkan pengaruh nyata $\mathrm{p}=0,05$ 
terhadap kadar protein, rerata kadar protein dari pengaruh proporsi daging ayam dan gel porang berkisar antara $15,18 \%-18,37 \%$, meskipun kadar protein sosis cukup tinggi dari standar minimal kadar protein pada sosis yaitu sebesar $13 \%$, namun kadar protein cenderung menurun akibat berkurangnya proporsi ayam yang ditambahkan pada sosis (Prastini, 2015).

\section{Kekenyalan}

Tabel 1. Rata-rata kekenyalan sosis nabati (Prastini et al., 2015)

\begin{tabular}{ccccc}
\hline & Proporsi & Kekenyalan & DMRT \\
Daging ayam & $:$ & Gel porang & $(\mathrm{N})$ & $-5 \%$ \\
\hline 95 & $:$ & 5 & $11.27 \mathrm{e}$ & \\
90 & $:$ & 10 & $10.30 \mathrm{de}$ & $2.75-3.02$ \\
85 & $:$ & 15 & $7.83 \mathrm{~cd}$ & \\
80 & $:$ & 20 & $5.07 \mathrm{bc}$ & \\
75 & $:$ & 25 & $3.17 \mathrm{ab}$ & \\
70 & $:$ & 30 & $2.17 \mathrm{a}$ & \\
\hline
\end{tabular}

Keterangan: Angka superscript yang berbeda pada kolom yang sama menunjukkan perbedaan yang signifikan $(\alpha=5 \%)$

Pada penelitian Prastini et al. (2015) rata - rata kekenyalan dari pengaruh proporsi daging ayam : gel porang bekisar antara 2.17-11.27\%. Analisis ragam menunjukkan proporsi daging ayam : gel porang memberikan pengaruh nyata $(\alpha=0.05)$ terhadap kadar air pada sosis. Semakin bertambahnya gel dan semakin berkurangnya daging ayam mengakibatkan kekenyalan sosis semakin kecil (lembek). Hal ini dikarenakan kadar air pada sosis yang semakin meningkat. Kadar air berpengaruh terhadap kekenyalan, semakin tinggi kadar air maka kekenyalan semakin rendah, jika kadar air rendah kekenyalan semakin meningkat (Huda et al., 2012).

Perubahan jumlah daging pada sosis akan mempengaruhi kekenyalan sosis. Semakin banyak daging yang digunakan, semakin baik pula kekenyalan dan tekstur sosis yang dihasilkan. Namun, semakin banyak bahan tambahan yang digunakan dalam pembuatan sosis, dapat mempengaruhi tekstur sosis bahkan dapat meninggalkan sifat khas yang dimiliki oleh sosis (Ktari et al., 2014).

Tabel 2. Rata-rata kekenyalan sosis nabati (Anggraeni, Widjanarkodan Ningtyas, 2014)

\begin{tabular}{ccccc}
\hline $\begin{array}{c}\text { Porang } \\
(\%)\end{array}$ & $:$ & Maizena & Kekenyalan & DMRT \\
\hline 2 & $:$ & 23 & $(\mathrm{~N})$ & $5 \%$ \\
3 & $:$ & 22 & $7.60 \mathrm{a}$ & - \\
4 & $:$ & 21 & $9.37 \mathrm{~b}$ & 1.06 \\
5 & $:$ & 20 & $9.80 \mathrm{bc}$ & 1.11 \\
6 & $:$ & $10.80 \mathrm{~cd}$ & 1.14 \\
7 & $:$ & 18 & $11.73 \mathrm{de}$ & 1.16 \\
\hline
\end{tabular}

Keterangan: Angka superscript yang berbeda pada kolom yang sama menunjukkan perbedaan yang signifikan $(\alpha=5 \%)$

Hasil penelitian Anggraeni, bahan baku yang digunakan dalam Widjanarko dan Ningtyas (2014) pembuatan sosis ayam sehingga teksturnya menunjukkan penambahan dan tepung menjadi kuat dan kompak. Semakin banyak maizena terhadap kekenyalan sosis ayam air yang terikat pada sosis maka dengan berbagai perlakuan berkisar antara kekenyalannya akan semakin kuat dan 7,60 - 12,77 N. Peningkatan kekenyalan ini kompak. Ketika dilakukan perebusan, disebabkan karena pada tepung porang kekenyalan produk juga semakin tinggi. Pati terdapat glukomanan yang bersifat yang diinteraksikan dengan hidrokoloid lebih hidrokoloid yang berfungsi sebagai binding mudah mengalami gelatinisasi yang ditandai agents yang dapat mengikat komponen atau dengan peningkatan viskositas yang lebih 
cepat dibandingkan dengan yang hanya hidrokoloid. Perbedaannya adalah bahwa menggunakan $100 \%$ pati (Supriyadi, 2017) Secara umum, pati yang diinteraksikan dengan hidrokoloid memiliki pola profil penambahan hidrokoloid meningkatkan viskositas pati secara keseluruhan (Winarno, gelatinisasi yang sama dengan pati tanpa 2004).

Tabel 3. Rata-rata kekenyalan sosis nabati (Sisik et al., 2012)

\begin{tabular}{|c|c|c|c|}
\hline & $\begin{array}{c}\text { Hardness } \\
(\mathrm{N})\end{array}$ & $\begin{array}{c}\text { Gumminess } \\
(\%)\end{array}$ & $\begin{array}{c}\text { Chewiness } \\
(\mathrm{Ncm})\end{array}$ \\
\hline \multicolumn{4}{|l|}{ Substituting corn oil $(O)$} \\
\hline Sheep tail fat & $62.33 \pm 6.22^{\mathrm{a}}$ & $31.97 \pm 3.91^{\mathrm{a}}$ & $26.86 \pm 3.40^{\mathrm{b}}$ \\
\hline Sheep tail fat/corn oil & $57.48 \pm 5.20^{\mathrm{b}}$ & $35.34 \pm 3.70^{\mathrm{b}}$ & $32.00 \pm 3.50^{\mathrm{a}}$ \\
\hline Significance & $* *$ & $* *$ & $* *$ \\
\hline \multicolumn{4}{|l|}{$\operatorname{Broccoli}(\%)(B)$} \\
\hline 0 & $62.87 \pm 5.21^{\mathrm{a}}$ & $35.66 \pm 2.66^{\mathrm{a}}$ & $31.33 \pm 3.24^{\mathrm{a}}$ \\
\hline 5 & $60.93 \pm 6.44^{\mathrm{b}}$ & $33.92 \pm 3.22^{\mathrm{b}}$ & $29.57 \pm 3.37^{b}$ \\
\hline 10 & $55.92 \pm 4.73^{\mathrm{c}}$ & $31.38 \pm 5.06^{\mathrm{c}}$ & $27.40 \pm 5.15^{\mathrm{a}}$ \\
\hline Significance & $* *$ & $* *$ & $* *$ \\
\hline \multicolumn{4}{|l|}{ Storage time $(S)$} \\
\hline $0 \mathrm{~d}$ & $55.88 \pm 4.93^{\mathrm{d}}$ & $33.53 \pm 6.04^{\mathrm{a}}$ & $29.28 \pm 6.08^{\mathrm{a}}$ \\
\hline $15 \mathrm{~d}$ & $60.17 \pm 6.57^{\mathrm{bc}}$ & $33.21 \pm 3.72^{\mathrm{a}}$ & $2859 \pm 3.77^{\mathrm{a}}$ \\
\hline $30 \mathrm{~d}$ & $57.95 \pm 4.93^{\mathrm{cd}}$ & $32.98 \pm 3.24^{\mathrm{a}}$ & $29.12 \pm 3.59^{\mathrm{a}}$ \\
\hline $45 \mathrm{~d}$ & $59.81 \pm 5.36^{\mathrm{bc}}$ & $33.85 \pm 3.11^{\mathrm{a}}$ & $29.58 \pm 3.36^{\mathrm{a}}$ \\
\hline $60 \mathrm{~d}$ & $61.38 \pm 6.42^{\mathrm{ab}}$ & $33.53 \pm 4.26^{\mathrm{a}}$ & $29.14 \pm 4.54^{\mathrm{a}}$ \\
\hline $75 \mathrm{~d}$ & $61.38 \pm 5.71^{\mathrm{ab}}$ & $33.79 \pm 4.31^{\mathrm{a}}$ & $30.03 \pm 4.59^{\mathrm{a}}$ \\
\hline $90 \mathrm{~d}$ & $62.79 \pm 7.20$ & $34.71 \pm 4.06^{\mathrm{a}}$ & $30.29 \pm 3.91^{\mathrm{a}}$ \\
\hline Significance & $* *$ & NS & NS \\
\hline $\mathrm{OxB}$ & NS & $* *$ & $* *$ \\
\hline OxS & NS & NS & NS \\
\hline $\mathrm{BxS}$ & NS & $*$ & $*$ \\
\hline
\end{tabular}

a-d: Any two means in the same column having the same letters in the same section are not significantly different at $\mathrm{p}>0.05$; SD: standard deviation; NS: not significant; $* \mathrm{p}<0.05 ; * * \mathrm{p}<0.01$.

Sisik et al. (2012) menyatakan bahwa penggantian lemak hewan dengan lemak nabati seperti margarin, minyak zaitun, dan minyak kelapa sawit menyebabkan penurunan kekerasan yang tidak signifikan. Hal ini dikarenakan lemak nabati memiliki

Tabel 4. Rata-rata kekenyalan sosis nabati (Syuhairah et al., 2016)

\begin{tabular}{|c|c|c|}
\hline \multirow{2}{*}{ Sample } & \multicolumn{2}{|c|}{ Parameters } \\
\hline & Hardness (kg) & Springiness $(\mathrm{mm})$ \\
\hline Control & $10.04 \pm 0.48$ & $8.82 \pm 0.10$ \\
\hline $\mathrm{CP}$ & $8.30 \pm 0.08^{\mathrm{aA}}$ & $7.74 \pm 0.28^{\mathrm{bcA}}$ \\
\hline $\mathrm{CP}$ & $6.09 \pm 0.04^{\mathrm{bB}}$ & $7.24 \pm 0.25^{\mathrm{bB}}$ \\
\hline $\mathrm{CP}$ & $4.65 \pm 0.21^{\mathrm{bC}}$ & $7.73 \pm 0.07^{\mathrm{bA}}$ \\
\hline $\mathrm{C}$ & $6.30 \pm 0.16^{\mathrm{bA}}$ & $7.55 \pm 0.30^{\mathrm{cA}}$ \\
\hline $\mathrm{C}$ & $6.29 \pm 0.44^{\mathrm{bA}}$ & $7.54 \pm 0.28^{\mathrm{bA}}$ \\
\hline $\mathrm{C}$ & $4.12 \pm 0.20^{\mathrm{bB}}$ & $7.57 \pm 0.23^{\mathrm{bA}}$ \\
\hline S & $8.13 \pm 0.22^{\mathrm{aA}}$ & $8.07 \pm 0.08^{\mathrm{abA}}$ \\
\hline S & $6.51 \pm 0.06^{\mathrm{aB}}$ & $8.04 \pm 0.14^{\mathrm{aA}}$ \\
\hline S & $4.61 \pm 0.14^{\mathrm{bC}}$ & $7.57 \pm 0.28^{\mathrm{bB}}$ \\
\hline $\mathrm{PC}$ & $8.37 \pm 0.22^{\mathrm{aA}}$ & $8.18 \pm 0.13^{\mathrm{aA}}$ \\
\hline $\mathrm{PC}$ & $6.64 \pm 0.13^{\mathrm{aB}}$ & $8.17 \pm 0.13^{\mathrm{aA}}$ \\
\hline $\mathrm{PC}$ & $4.84 \pm 0.11^{\mathrm{aC}}$ & $8.14 \pm 0.20^{\mathrm{aA}}$ \\
\hline $\mathrm{OM}$ & $4.36 \pm 0.04^{\mathrm{cA}}$ & $6.60 \pm 0.18^{\mathrm{dA}}$ \\
\hline $\mathrm{OM}$ & $3.73 \pm 0.15^{\mathrm{cB}}$ & $6.53 \pm 0.40^{\mathrm{cA}}$ \\
\hline $\mathrm{OM}$ & $3.34 \pm 0.37^{\mathrm{cB}}$ & $6.54 \pm 0.03^{\mathrm{cA}}$ \\
\hline
\end{tabular}

Keterangan: Angka superscript yang berbeda pada kolom yang sama menunjukkan perbedaan yang signifikan $(\alpha=5 \%)$ 
Syuhairah et al. (2016) menyatakan bahwa adanya penurunan kekerasan seiring penambahan konsentrasi bahan baku pada konsentrasi $30 \%$ hingga 50\%. Jenis sayur juga mempengaruhi penurunan kekenyalan pada produk vegetables, pada peningkatan pomace tomat yang diputihkan dan bubuk jamur tiram yang ditambahkan ke adonan sosis menyebabkan berkurang secara signifikan pada kekenyalan sosis, selain jenis sayur yang ditambahkan pada penelitian ini juga menunjukkan bahwa kandungan daging ayam yang lebih rendah akan berkontribusi pada rata - rata kekenyalan lebih rendah.

Tabel 4. Rata-rata kekenyalan sosis nabati (Hidayat et al., 2017)

\begin{tabular}{lccccc}
\hline \multirow{2}{*}{ Parameter } & \multicolumn{5}{c}{ Formula $(\%$ meat subtituted with TVP) } \\
& 0 & 10 & 20 & 30 & 40 \\
\hline $\mathrm{L}^{*}$ & $47.98 \pm 1.50^{\mathrm{a}}$ & $47.43 \pm 1.74^{\mathrm{a}}$ & $48.01 \pm 0.85^{\mathrm{a}}$ & $50.21 \pm 1.21^{\mathrm{b}}$ & $51.95 \pm 1.50^{\mathrm{b}}$ \\
$\mathrm{a}^{*}$ & $5.66 \pm 0.70^{\mathrm{a}}$ & $5.62 \pm 0.97^{\mathrm{a}}$ & $5.83 \pm 0.93^{\mathrm{a}}$ & $5.77 \pm 0.35^{\mathrm{a}}$ & $5.43 \pm 0.25^{\mathrm{a}}$ \\
$\mathrm{b}^{*}$ & $7.87 \pm 0.44^{\mathrm{a}}$ & $7.86 \pm 0.75^{\mathrm{a}}$ & $7.94 \pm 0.54^{\mathrm{a}}$ & $8.49 \pm 0.36^{\mathrm{ab}}$ & $9.03 \pm 0.38^{\mathrm{b}}$ \\
$\Delta \mathrm{E}$ & - & 0.5515 & 0.1863 & 2.3172 & 4.1424 \\
$\mathrm{pH}$ & $6.45 \pm 0.11^{\mathrm{a}}$ & $6.50 \pm 0.04^{\mathrm{a}}$ & $6.525 \pm 0.05^{\mathrm{a}}$ & $6.51 \pm 0.05^{\mathrm{a}}$ & $6.49 \pm 0.08^{\mathrm{a}}$ \\
Hardness $(\mathrm{N})$ & $1.0042 \pm 0.25^{\mathrm{b}}$ & $0.8053 \pm 0.05^{\mathrm{a}}$ & $0.6962 \pm 0.11^{\mathrm{a}}$ & $0.6981 \pm 0.15^{\mathrm{a}}$ & $0.6757 \pm 0.07^{\mathrm{a}}$ \\
WHC $(\%)$ & $86.58 \pm 1.33^{\mathrm{a}}$ & $86.67 \pm 1.50^{\mathrm{a}}$ & $87.53 \pm 0.97^{\mathrm{ab}}$ & $89.02 \pm 0.96^{\mathrm{b}}$ & $89.14 \pm 1.75^{\mathrm{b}}$ \\
Cooking Yield $(\%)$ & $100.39 \pm 0.92^{\mathrm{ab}}$ & $99.78 \pm 0.86^{\mathrm{a}}$ & $100.57 \pm 1.20^{\mathrm{ab}}$ & $101.02 \pm 1.04^{\mathrm{ab}}$ & $101.58 \pm 1.13^{\mathrm{ab}}$ \\
\hline
\end{tabular}

Keterangan: Angka superscript yang berbeda pada kolom yang sama menunjukkan perbedaan yang signifikan $(\alpha<5 \%)$

Hidayat et al. (2017) menyatakan bahwa kekerasan beberapa formula sosis (dengan dan tanpa penambahan TVP). Berdasarkan Gambar 4.6 penambahan TVP secara signifikan mengurangi kekerasan sosis $(\mathrm{P}<0,05)$ semakin tinggi penambahan TVP yang ditambahkan maka akan mengurangi kekerasan pada sosis.. Substitusi daging dengan TVP akan mengurangi kadar lemak akan mempengaruhi tekstur sosis, selain itu pergantian daging sapi dengan TVP dapat mengurangi kadar lemak dalam sosis. Alasan lain yang dapat dipengaruhi oleh peningkatan kadar air dalam sosis diganti dengan TVP.

Dari hasil studi literatur menyebutkan bahwa pada perlakuan sosis nabati terhadap penambahan tepung kacang hijau dan tepung biji nangka berpengaruh signifikan pada kekenyalan sosis nabati. Hal ini dikarenakan tepung biji nangka memiliki amilopektin yang tinggi yaitu 49,5\% (Supriyadi, 2017) dan kandungan pati pada kacang hijau juga tinggi yakni sebesar 80,89\% (Seuri, 2012). Sehingga peningkatan proporsi tepung biji nangka dan tepung kacang hijau dapat menyebabkan peningkatan kekenyalan pada sosis.

\section{Warna}

Hasil uji hedonik, dilakukan uji friedman, menunjukkan bahwa $\mathrm{F}$ hitung $(22,57)$ lebih besar dari $F$ tabel $(15,57)$ dengan rata - rata tidak suka $(2,48)$ hingga suka $(3,44)$. Hal ini menunjukkan bahwa perlakuan sosis terhadap penambahan kacang hijau dan biji nangka berpengaruh signifikan pada warna. 


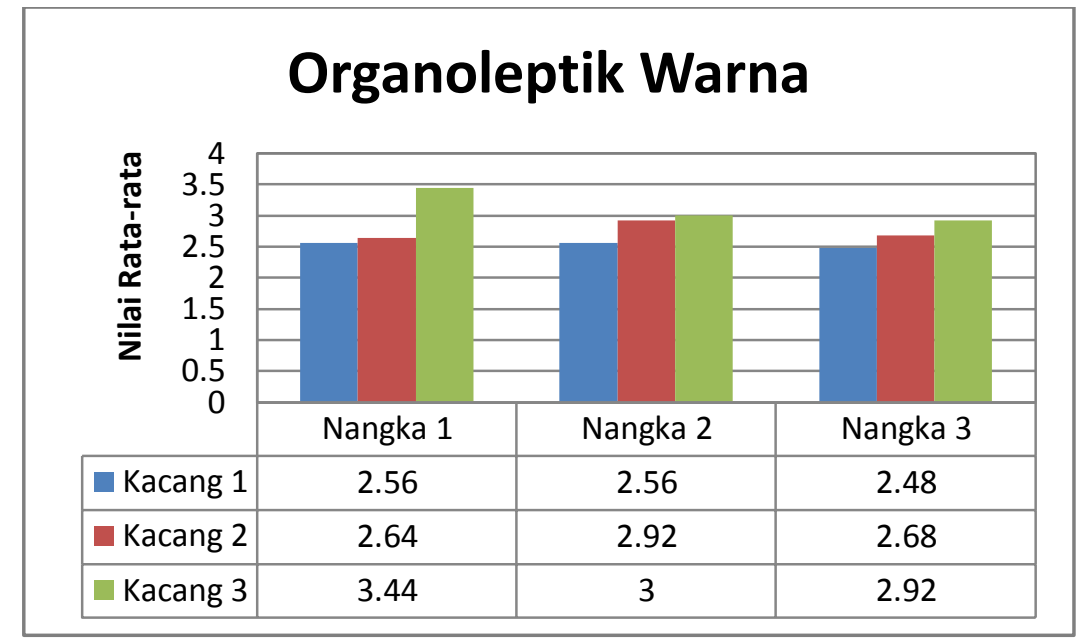

Gambar 5. Grafik rata-rata kesukaan terhadap warna sosis nabati

Nilai tertinggi tingkat kesukaan panelis terhadap warna sosis berbahan baku kacang hijau dan biji nangka yaitu N1K3 ( tepung biji nangka 5\% + tepung kacang hijau 5\%). Dalam penelitian ini Warna pada sosis nabati berbahan baku tepung biji nangka dan tepung kacang hijau kurang disukai panelis karena warna sosis nabati kurang menarik, sosis nabati berwarna kekuningan hingga kecokelatan.. Hal ini disebabkan pada kacang hijau dan pada lendir biji nangka memiliki senyawa fenol (Maklffoel, 1982; Hadi, Yusmarinidan Efendi, 2017). Penambahan sosis tepung kacang kedelai membuat warna menjadi lebih cerah dan kekuningan (Thomas et al., 2008; Huda et al., 2012) .Penggantian daging sapi dengan tepung kacang kedelai akan menyebabkan konsentrasi pigmen daging sapi yang lebih rendah misalnya mioglobin merah terang (ketika dalam bentuk deoksi moglobin) yang digantikan oleh tepung kacang kedelai yang memiliki warna kekuningan yang lebih cerah (Asgar et al., 2010) pergantian sosis dengan beberapa serat seperti tomat dan lainnya memberi pengaruh juga terhadap peningkatan warna kuning (Savadkoohi

et al., 2014). Sehingga dari penelitian ini dapat dilihat semakin meningkat penambahan tepung kacang hijau dan tepung biji nangka menyebabkan penurunan nilai kesukaan panelis terhadap warna pada sosis nabati.

\section{Aroma}

Hasil uji hedonik, dilakukan uji friedman, menunjukkan bahwa $\mathrm{F}$ hitung $(31,83)$ lebih besar dari $\mathrm{F}$ tabel $(15,57)$. dengan rata - rata netral $(2,56)$ hingga suka $(3,68)$. Hal ini menunjukkan bahwa perlakuan sosis terhadap penambahan kacang hijau dan biji nangka berpengaruh signifikan pada.

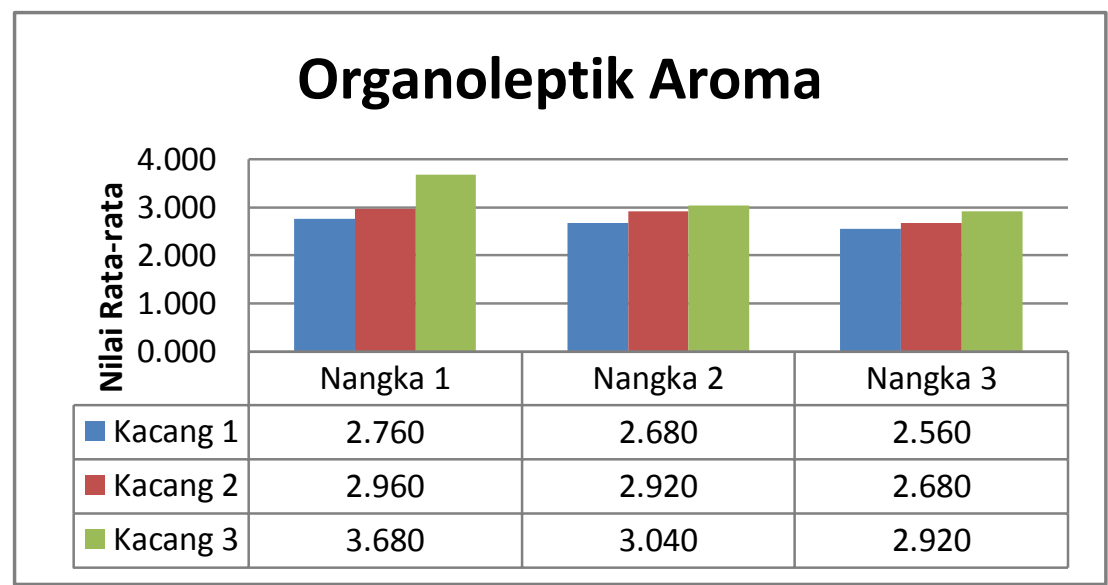

Gambar 6. Grafik rata-rata kesukaan terhadap aroma pada sosis nabati 
Nilai tertinggi tingkat kesukaan panelis terhadap aroma sosis nabati berbahan baku kacang hijau dan biji nangka yaitu N1K3 ( tepung biji nangka $5 \%$ + tepung kacang hijau 5\%). Dari penelitian ini penambahan proporsi tepung kacang hijau dan tepung biji nangka pada sosis nabati menyebabkan penurunan nilai kesukaan panelis terhadap aroma pada sosis nabati. Hal ini dikarenakan biji nangka memiliki aroma dan cita rasa langu yang khas (Supriyadi, 2014).aroma langu pada biji nangka ini disebabkan oleh adanya aktivitas enzim liposidase yang menghidrolisis atau menguraikan lemak pada biji nangka menjadi senyawa yang beroaroma langu seperti etil-fenil-keton (Hadi, Yusmarinidan Efendi, 2017).
Aroma langu pada sosis nabati juga berasal dari kacang hijau, bau langu pada kacang hijau disebabkan aktivitas enzim lipogenase akan menyerang rantai asam lemak tidak jenuh dan menghasilkan sejumlah senyawa yang lebih kecil bobot molekulnya, terutama senyawa aldehid dan keton (Pratama, 2014)

\section{Tekstur}

Hasil uji hedonik, dilakukan uji friedman, menunjukkan bahwa $\mathrm{F}$ hitung $(72,15)$ lebih besar dari $F$ tabel $(15,57)$. Tingkat kesukaan panelis terhadap terhadap sosis nabati berbahan baku kacang hijau dan biji nangka berada pada range antara tidak suka - suka yaitu $1,72-3,76$.

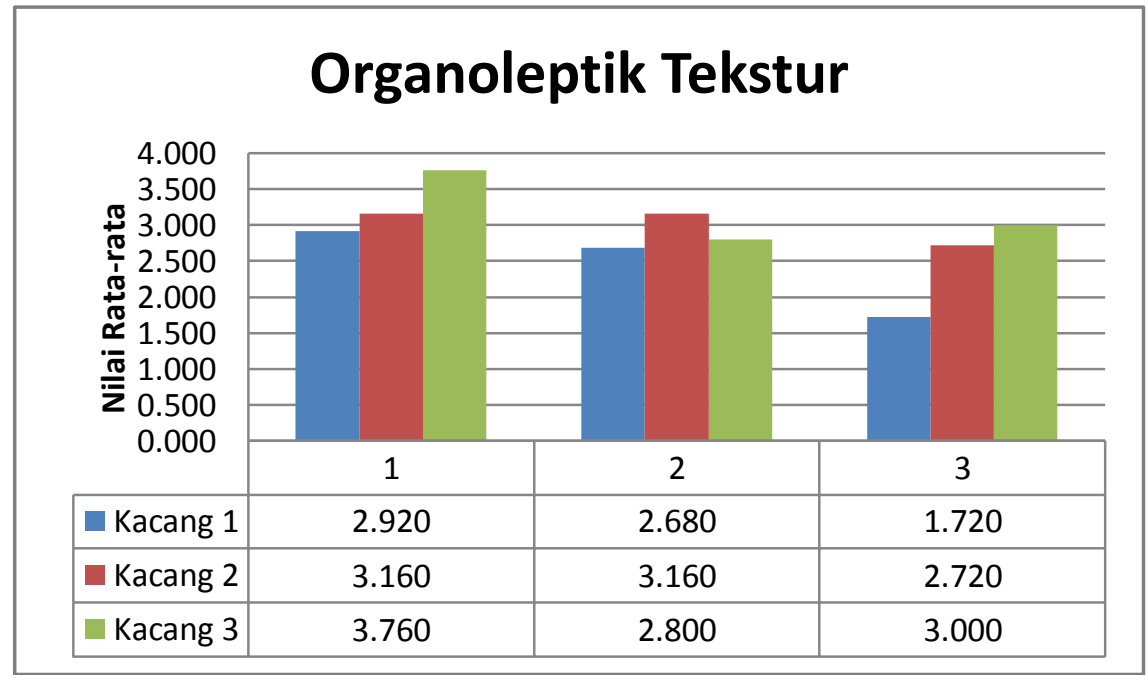

Gambar 7. Grafik rata-rata kadar karbohidrat sosis nabati

Nilai tertinggi tingkat kesukaan panelis terhadap tekstur sosis berbahan baku kacang hijau dan biji nangka yaitu N1K3 (tepung biji nangka 5\% + tepung kacang hijau 5\%). Dari penelitian ini penambahan proporsi tepung kacang hijau dan tepung biji nangka pada sosis nabati menyebabkan penurunan nilai kesukaan panelis terhadap tekstur pada sosis nabati.

Kadar Pati pada bahan tidak memiliki pengaruh yang signifikan terhadap tekstur sosis setelah pemasakan, kekenyalan produk menurun hingga menjadi lembek atau meningkat hingga menjadi keras ini dipengaruhi oleh kadar air pada sosis (Huda et al., 2012). Selain jumlah kadar air penggantian jenis protein dan lemak nabati pada juga mempengaruhi tekstur kekenyalan pada sosis nabati. Pada penelitian Ktari et al. (2014) menyebutkan pengaruh substitusi daging sapi dengan bahan lain seperti konjacjelly dan serat nanas juga menurunkan kekerasan yang dapat dikaitkan dengan penambahan air. Penggantian lemak dengan serat yang berbeda telah terbukti meningkatkan sifat tekstur pada sosis (Hidayat et al., 2017). Penggunaan minyak jagung mengurangi kekerasan dan meningkatkan kekenyalan, penggunaan minyak zaitun sebagai pengganti lemak hewani juga berpengaruh demikian pada sosis dengan penambahan brokoli (Sisik et al., 2012).

Tepung biji nangka memiliki amilopektin lebih rendah dibanding kadar 
amilosanya yaitu 49,5\% (Supriyadi, 2017) .Tekstur kesukaan mie semakin rendah seiring semakin tingginya tepung kimpul dan tepung kacang hijau ditambahkan karena rendahnya kandungan amilosa yang menyebabkan tidak adanya gluten pada mie (Pratama et al., 2014).

\section{Rasa}

Hasil uji hedonik, dilakukan uji friedman, menunjukkan bahwa $\mathrm{F}$ hitung $(48,83)$ lebih besar dari $F$ tabel $(15,57)$. tingkat kesukaan panelis terhadap terhadap sosis nabati berbahan baku kacang hijau dan biji nangka berada pada range antara tidak suka - suka yaitu 1,92- 3,64.

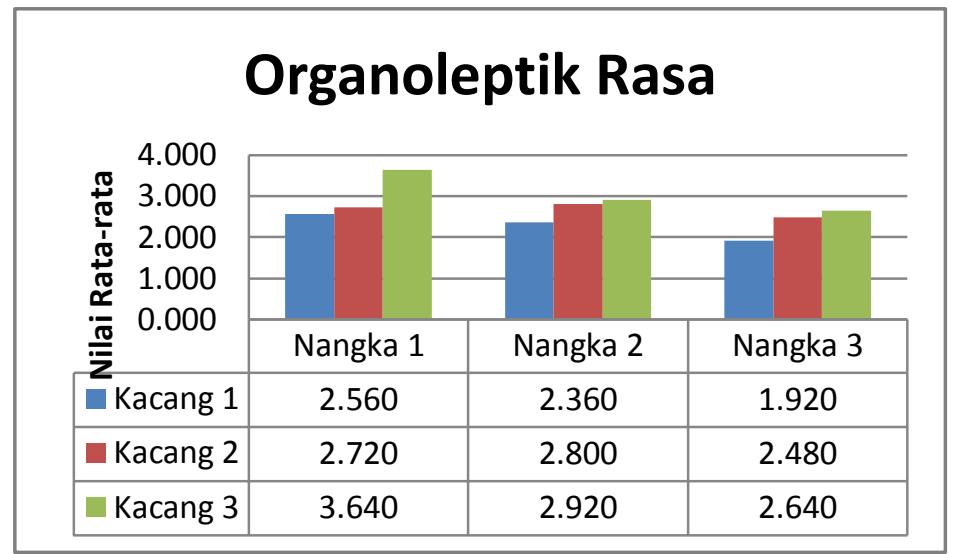

Gambar 8. Grafik rata-rata kesukaanterhadap rasa sosis nabati

Nilai tertinggi tingkat kesukaan panelis terhadap rasa sosis berbahan baku kacang hijau dan biji nangka yaitu N1K3 ( tepung biji nangka 5\% + tepung kacang hijau 5\%). Dari penelitian ini penambahan proporsi tepung kacang hijau dan tepung biji nangka pada sosis nabati menyebabkan penurunan nilai kesukaan panelis terhadap rasa pada sosis nabati. Hal ini dikarenakan pada tepung biji nangka mengandung senyawa asam volatil (saponin) yang memiliki rasa pahit, senyawa saponin berasal dari granula pati pada tepung biji nangka yang mengalami hidrolisis (Hadi, Yusmarinidan Efendi,2017). sehingga peningkatan proporsi tepung biji nangka akan menghasilkan produk yang semakin pahit. Penambahan subtitusi tepung biji nangka pada rasa onde-onde ketawa menghasilkan semakin berasa cita rasa khas tepung biji nangka (Supriyadi, 2017). Penambahan kacang - kacangan pada produk tidak boleh lebih dari 2\% karena akan merusak rasa pada produk (Huda et al., 2017). Pada tepung kacang hijau memiliki rasa langu, sehingga peningkatan proporsi tepung kacang hijau pada sosis nabati, rasa pahit ini berasal dari oksidasi asam linolenik oleh enzim lipogenase (Pratama et al., 2014). Larasati (2017) menyatakan bahwa sosis tempe memiliki rasa kapur dan rasa pahit yang berasal dari dalam kedelai yang disebabkan adanya senyawa saponi dan sapogenol pada kacang-kacangan.

\section{Indeks efektifitas}

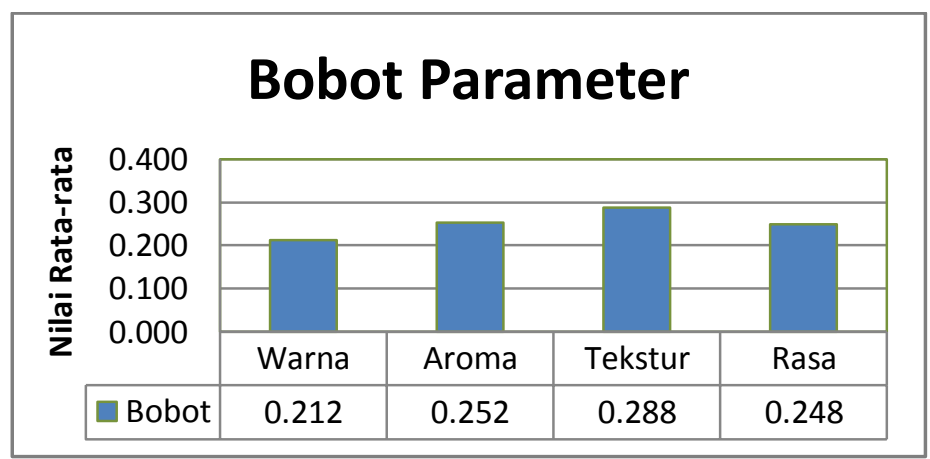

Gambar 9. Grafik bobot parameter sosis nabati 
Untuk menentukan perlakuan terbaik digunakan metode indeks efektivitas (De Garmo et al., 1994).Metode ini dilakukan pada parameter organoleptik. Parameter meliputi warna, aroma, rasa dan tekstur. Bobot berturut-turut mulai yang tertinggi yaitu tekstur $(0,288)$, aroma $(0,252)$, rasa
$(0,248)$ dan warna $(0,212)$. Dalam penelitian ini, ditemukan bobot tertinggi pada tekstur sebesar 0,288, Hal ini dikarenakan kandungan pati pada tepung biji nangka dan tepung kacang hijau. Selain itu kadar air pada sosis juga mempengaruhi tekstur pada sosis.

\section{Perlakuan terbaik}

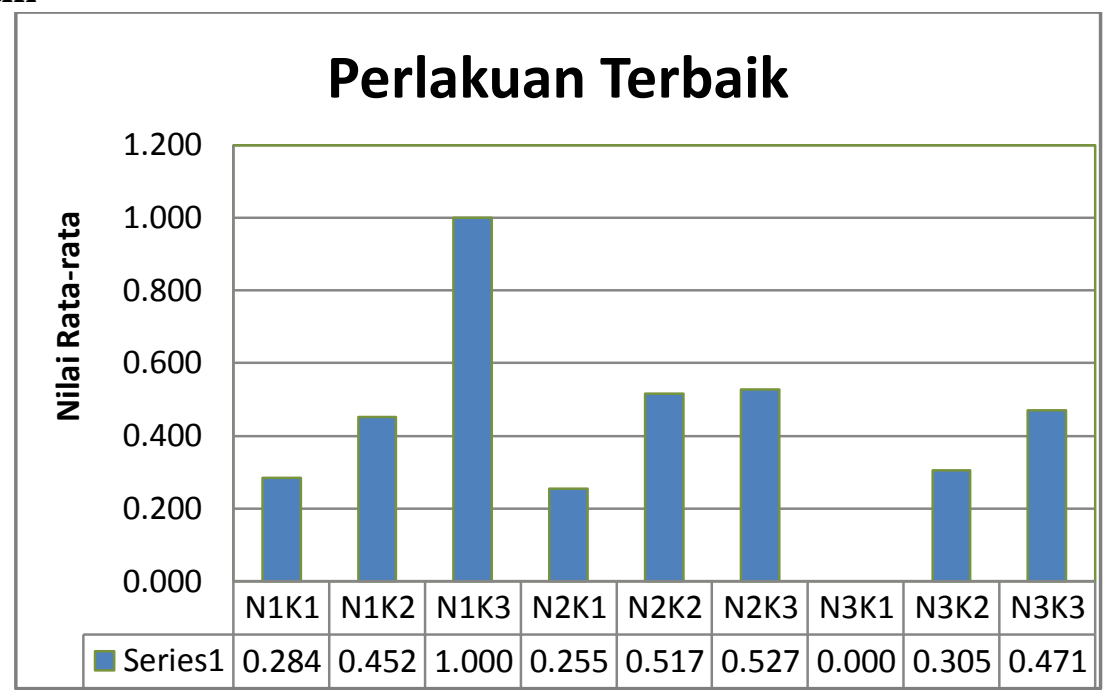

Gambar 10.Perlakuan terbaik pada sosis nabati

Hasil perhitungan ini menunjukkan bahwa perlakuan terbaik yaitu pada N1K3 (tepung biji nangka $25 \%$ + tepung kacang hijau 25\%) dengan nilai parameter organoleptik yaitu warna 3,44 (netral), aroma 3,680 (suka), tekstur 3,76 (suka), rasa 3,60 (suka). Dapat disimpulkan bahwa semakin meningkat proporsi tepung biji nangka dan tepung kacang hijau yang ditambahkan pada sosis nabati akan berpengaruh pada menurunnya rerata kesukaan panelis, namun menurut hasil data literatur semakin meningkat proporsi tepung biji nangka dan tepung kacang hijau yang ditambahkan pada sosis nabati akan berpengaruh pada meningkatnya kadar protein.

Hal ini dikarenakan pada tepung biji nangka dan tepung kacang hijau mengandung senyawa saponin yang menghasilkan rasa langu. Kandungan pati pada tepung biji nangka dan tepung kacang hijau yang tinggi dan penggantian lemak hewani dengan minyak kelapa sawit dapat mempengaruhi tekstur dari sosis nabati. Kandungan etil-fenil-keton pada tepung biji nangka dan kandungan aldehid dan keton pada tepung kacang hijau dapat mempengaruhi aroma pada sosis nabati. Pada tepung biji nangka dan kacang hijau memiliki senyawa fenol yang dapat mempengaruhi warna pada sosis nabati. Namun biji nangka memiliki kandungan protein $12,9 \%$ dan kacang hijau memiliki kandungan protein sebesar $22 \%$ sehingga peningkatan proporsi tepung biji nangka dan tepung kacang hijau dapat menurunkan nilai rata - rata uji organoleptik dan kekenyalan pada sosis nabati, namun penambahan proporsi tepung biji nangka dan tepung kacang hijau dapat meningkatkan kadar protein pada sosis nabati.

\section{KESIMPULAN}

Berdasarkan penelitian ini pengaruh proporsi biji nangka (Artocarpus heterophyllus L.) dan kacang hijau (Phaseolus radiatus L.) pada pembuatan sosis nabati, dapat disimpulkan: 1) Proporsi yang tepat untuk penambahan tepung biji nangka dan tepung kacang hijau yang tepat untuk pembuatan produk sosis nabati ditinjau 
dari fisikokimia yaitu N3K1 dengan kadar protein sebesar 14.71, dan kekenyalan pada N1K3. 2) Proporsi yang tepat untuk penambahan tepung biji nangka dan tepung kacang hijau yang tepat untuk pembuatan produk sosis nabati ditinjau dari organoleptik yaitu N1K3 (tepung biji nangka 25\% + tepung kacang hijau 25\%) dengan nilai parameter organoleptik yaitu warna 3,44 (netral), aroma 3,680 (suka), tekstur 3,76 (suka), rasa 3,60 (suka). Saran yang dapat disampaikan berdasarkan penelitian yang telah dilakukan adalah: 1) Penelitian selanjutnya diharapkan dapat meneliti secara langsung parameter fisikokimia pada pengaruh penambahan proporsi tepung biji nangka dan tepung kacang hijau untuk membandingkan dengan hasil literatur pada penelitian ini. 2) Penelitian selanjutnya diharapkan dapat meneliti perbandingan karakteristik fisikokimia dan organoleptik sosis nabati berbahan baku tepung biji nangka dan tepung kacang hijau dengan sosis yang beredar di pasaran.

\section{UCAPAN TERIMAKASIH}

Terima kasih kepada dosen pembimbing, dosen penguji serta temanteman seangkatan yang telah membantu proses penelitian ini.

\section{DAFTAR PUSTAKA}

Adiandri, R. S., Hidayah, N., \& Rahayu, E. (2014) Efek pengolahan terhadap kandungan oligosakarida dan sifat fisikokimia tepung kedelai dan kacang hijau. Prosiding Seminar Hasil Penelitian Tanaman Aneka Kacang dan Umbi. Bogor: Balai Besar Penelitian dan Pengembangan Pascapanen Pertanian.

Ambari, D. P., Anwar, F., \& Damayanthi, E. (2014).Formulasi sosis analog sumber protein berbasis tempe dan jamur tiram sebagai pangan fungsional kaya serat pangan.Jurnal Gizi dan Pangan, 9(1), 65-72.

Anggraeni, D. A., Widjanarko, S. B., \&
Ningtyas, D. W. (2014). Proporsi tepung porang dan maizena terhadap karakteristik sosis ayam.Jurnal Pangan dan Agroindustri, 2(3), 214-223.

Apisittiwong, T., Boonsiriwit, A., Thephuttee1, N., \& Thancharoenkul, T. (2019). Development of halal chinese fish sausage using different types of lipid. CMU J. Nat. Sci, 18(1), 1-13. $\quad$ https://doi.org/10.12982/ CMUJNS.2019.0001

Dolongseda, W., Ludong, M. M., \& Djarkasi, G. S. S. (2017). Kajian sifat sensoris tortila yang disubstitusi tepung biji nangka. E-Journal Universitas Sam Ratulangi, 1(7), 1-11.

Gupta, D., Mann, S., Sood, A.,\& Gupta, R. K. (2011). Phytochemical, nutritional and antioxidant activityevaluation of seeds of jackfruit (Artocarpous heterolphyllus $\quad$ L.). International Journal of Pharma and Bio Sciences, 2(4), 336-345.

Hadi, N., Yusmarini., \& Efendi, R. (2017). Pemanfaatan tepung biji nangka dan tepung jagung dalam pembuatan flakes. Jurnal FAPERTA, 4(2), 1-12

Hidayat, B.T., Wea, A., \&Andriati, N. (2017).Physicochemical, sensory attributes and protein profile by SDSPAGE of beef sausage substituted with texturized vegetable protein. Food Research, 2(1), 20-31. https://doi.org0/ 10.26656/fr.2017.2(1).106

Huda, N., Alistair, T. L. J., Lim, H. W., \& Nopianti, R. (2012). Some quality characteristics of malaysian commercial fish sausage. Pakistan Journal of Nutrition, 11(8), 700-705. https://doi.org/10.3923/pjn.2012.798.8 03

Jayus., Setiawan, D., \& Giyarto. (2016). Physical and chemical characteristics of jackfruit (Artocarpus heterophyllus lamk.) seeds flour produced under fermentationprocess by lactobacillus plantarum. Agriculture and Agricultural Science Procedia, 9(1), 342-347. https://doi.org/doi:10.1016/ j.aaspro.2016.02.148 
Kim, D. H., Shin, D. M., Seo1, H. G.,\& Han, S. G. (2019). Effects of konjac gel with vegetable powders as fat replacers in frankfurter-type sausage. Asian Australas Journal Animal Science, 32(8), 1195-1204. https://doi.org/ 10.5713/2019.18.0781

Nusa, M. I.,Fuadi, M., \& Fatimah, S. (2014). Studi pengolahan biji buah nangka dalam pembuatan minuman instan. Agrium, 19(1), 31-38

Pradipta, I. B. Y. V., \& Putri, W. D. R. (2015).Pengaruh proporsi tepung terigu dan tepung kacang hijau serta subtitusi dengan tepung bekatul dalam biscuit. Jurnal Pangan dan Agroindustri, 3(3), 793-802.

Prayitno, A. H., Miskiyah, F., Rachmawati, A. V., Baghaskoro, T. M., Gunawan, B. P., \& Soeparno (2012). Karakteristik sosis dengan fortifikasi $\beta$ caroten dari labu kuning (Cucurbita moschata). Buletin Peternakan, 33(2), 111-118. https://doi.org/10.21059/ buletinpeternak.v33i2.124

Singal, C. Y., Nurali, E. J. N., Koapaha, T., \&Djarkasi, G. S. S. (2013). Pengaruh penambahan tepung wortel (Daucus carota L.) pada pembuatan sosis ikan gabus (Ophiocephalus striatus) .EJournal Universitas Sam Ratulangi, 3(6), 1-8.

Sisik, S.,Kaban, G.,Karaoglu, M. M.,\&Kaya, M. (2012). Effects of corn oil and broccoli on instrumental texture and color properties of bolognatypesausage.International Journal of Food Properties, 15(1), 1161-1169. https://doi.org/10.1080/10942912.2010 .517339

Supriyadi, A. (2017). Pengaruh substitusi tepung biji nangka (Artocarpus heterphyllus) terhadap mutu organoleptik kue onde-onde ketawa.Ejournal boga , 3(1), 225-233.

Syuhairah.,Huda, N., Syahariza, Z. A., \& Fazilah, A. (2016). Effects of vegetable incorporation on physical and sensory characteristics of sausages.Asian Journal of Poultry Science, 10(3), 117125. https://doi.org/10.3923/.2016. 117.125

Theivasanthi, T., \& Alagar, M. (2011). An insight analysis of nano sized powder of jackfruit seed. Nano Biomedicine and Engineering, 3(3), 163-168. https://doi.org/10.5101/nbe.v3i3.p163168. 